\title{
Model of septic arthritis by intravenous inoculation of staphylococcus aureus in wistar rats ${ }^{1}$
}

\author{
Flamarion dos Santos Batista ${ }^{2}$ \\ Osvaldo Malafaia ${ }^{3}$ \\ Jurandir Marcondes Ribas Filho ${ }^{3}$ \\ Nicolau Gregory Czeczko ${ }^{3}$ \\ João Carlos Domingues Repka ${ }^{4}$
}

Batista FS, Malafaia O, Ribas Filho JM, Czeczko NG, Repka JCD. Model of septic arthritis by intravenousinoculation of staphylococcus aureus in wistar rats. Acta Cir Bras [serial online] 2004 Vol 19 Special Edition. Available on URL: http://www.scielo.br/acb.

ABSTRACT - An experimental model of septic arthritis by monobacterial inoculation of Staphylococcus aureus $10 .{ }^{9}$ in Wistar rats dorsal penis vein is describred.

KEY WORDS : Models, animal. Arthritis, infectious. Rats.

\section{Introduction}

Although septic arthritis is a common disease among human beings, reproducible experimental studies of septic arthritis in rats were not found in the consulted literature.

The aim of the present study was to develop a model of septic arthritis in Wistar rats ${ }^{1,2,3}$ by intravenous inoculation ${ }^{4,1,2,5,6,7,8,9}$ of Staphylococcus aureus, by evaluating elbow, soldras ${ }^{10}$ and tail articulations; day of appearance ${ }^{6,3,11,12,13}$ of the arthritis by clinical observation; its intensity, the macroscopic examination of the articulation presenting arthritis, the bacteriological evaluation of articulation secretion, hemoculture and the histophatological examination of this articulations.

\section{Proposition}

This article has as proposition to divulge and to give an account of the use of an experimental model of induced septic arthritis by inoculation in the dorsal vein of the rat penis.

\section{Method description}

This study was realized at the Medical Research Institute of Hospital Universitário Evangélico de Curitiba - IPEM/HUEC. This project was approved by the Ethical and Research Committee of HUEC.

\footnotetext{
1. Work realized at Hospital Universitário Evangélico de Curitiba - Faculdade Evangélica de Medicina do Paraná FEPAR - Instituto de Pesquisas Médicas IPEM/HUEC 


\section{Animals}

114 male adult rats were utilized, (Rattus norvegicus albinus, Rodentia mammalia) of lineage Wistar, obtained in vivarium of Instituto de Tecnologia do Paraná (TECPAR) with average weight of $177,51 \mathrm{~g}$ in the beginning of the experimental study.

In specific conditions, in the Animals Training Center of IPEM/HUEC, all 114 rats were identified and caged in groups of 6 in 19 proper numerated cages. The feeding consisted of a specific feed for the species utilized in this study, Nuvita ${ }^{\circledR}$ - Nuvital, and water ad libitum, without the addition of antibiotics.

During a week before the beginning of the experimental study, the rats were manipulated in adequate circumstances of hygiene and climatized to the new environmental conditions of temperature and illumination.

At the end of this period the animals were distributed in two groups, a control group with 18 rats and the other, the experimental group with 96 animals.

\section{Induction of experimental arthritis}

\section{Staphylococcus aureus inoculum preparation}

A strain of Staphylococcus aureus from the collection of the Microbiology and Immunology laboratory of Faculdade Evangélica de Medicina do Paraná was utilized in this study. This strain was isolated originally from the hemoculture of a patient of Intensiv Care Unit of HUEC. This strain was ressuspended and cultivated in Brain and Heart infusion ${ }^{\circledR}$ (Biobrás), for 24 hours at $37^{\circ} \mathrm{C}$.

An aliquot of the bacterial suspension was collected for counting the formed colonies in the culture. This aliquot consisted in preparing 12 serial dilutions of the sample in isotonic saline solution, corresponding to $1: 10^{1}, 1: 10^{2}, 1: 10^{3}, 1: 10^{4}, 1: 10^{5}, 1: 10^{6}, 1: 10^{7}, 1: 10^{8}, 1: 10^{9}, 1: 10^{10}, 1: 10^{11}, 1: 10^{12} .1 \mathrm{ml}$ of each dilution was transferred to two Petri dishes (A and B) and $15 \mathrm{ml}$ of melted Soy Tripticasein Agar ${ }^{\circledR}$ (Biobrás) were added to the inoculum at $45^{\circ} \mathrm{C}$. After the solidification of the culture media, all the plates were incubated for 24 hours at $37^{\circ} \mathrm{C}$. At the end of this period, all colonies forming unites (CFU) were evaluated in the Petri dishes (A and B) and the average and standard deviation were calculated (1.041,75 $\pm 51,43 \times 10^{6}$ ) per $\mathrm{ml}$ of Staphylococcus aureus inoculum concentration.

\section{Inoculation}

The rats were brought to the surgery room in their respective cages and before inoculation, they were anaesthetized in a closed compartment by inalatory effect of ether solution at $70 \%$ (ethyl ether and ethanol) $)^{4}$.

In the control group a injection was made in the vein dorsalis penis, consisting of $0,1 \mathrm{ml}$ of isotonic saline solution (Sodium Chloride ${ }^{\circledR}$ at $0,9 \%$ - Fresenius) for each $10 \mathrm{~g}$ of animal weight. For that, all rats were put in dorsal decubitous being the penis tractionated and the vein punctionated with a needle of 13 x 0,45 millimeters (mm).

In the experimental group the inoculation/injection was made in the vein dorsalis penis, consisting of $0,1 \mathrm{~mL}$ of $10^{9}$ monobacterial inoculum of Staphylococcus aureus for each $10 \mathrm{~g}$ of the rats weight. For the venous punction the same procedure for the control group was utilized. This protocol was established after previous pilot study.

\section{Evolution and clinical evaluation of animals arthritis}

For the evolution and the clinical evaluation of the animals arthritis, the criteria adapted and utilized were cited by various authors ${ }^{8,12,13,14}$. All the rats were analyzed individually. Cephalod and 
caudal feet, as well as the tale were inspected by two observers in pre-established aleatory regular intervals (1, 2, 3, 5, 6, 8, 12, 15, 19, 22 e 23 days) after the inoculation.

\section{Follow up of the arthritis}

The follow up of induced septic arthritis in rats was held at the Surgery Center for animals of IPEM/HUEC, at the Microbiology and Immunology laboratory of Faculdade Evangélica de Medicina do Paraná and at Pathological Anatomy laboratory of HUEC.

\section{Euthanasia}

All the rats, of the control and experimental groups were sacrificed in a closed compartment for the lethal action of ether solution at 70\% (ethyl ether and ethanol). The rats were aleatory killed, in preestablished intervals, i.e., in 6, 8, 12, 15, 19, 22 and 23 days after bacterial inoculation.

\section{Cardiac punction}

Immediately after euthanasia intra-cardiac punction was made with a sterile $5 \mathrm{ml}$ syringe and needle of $40 \times 1,2 \mathrm{~mm}$ for blood collection. The blood samples were transferred and conditioned in flasks with Soy Tripticasein broth ${ }^{\circledR}$ (Biobrás) for hemoculture. This material was identified and sent to the laboratory for microbiological studies, after being submitted to previous laboratory routine procedures.

\section{Necropsy}

Necropsy was realized in surgery room, being each rat put in dorsal decubitous position, on a specific wooden board for animals handling, proceeding antisepsis with alcohol iodine solution for articulation dissection with sweeling and/or erithem in the experimental group and randomly in the control group, being made antero-medial approach of approximately $2,5 \mathrm{~cm}$ reaching the skin and mucous pelt for secretion collection and to withdrawn the joint segment.

\section{Articulation macroscopic observation}

The macroscopic evaluation of the articulation was realized by observation of the presence or absence of liquid collection, type of secretion and septic joint.

\section{Secretion sampling and conditioning}

By visualization with a binocular stereomicroscope Carl Zeiss ${ }^{\circledR}$ (magnification of 12,5X) and by utilizing a sterile swab the collection of the committed joint secretion was realized, being immediately conditioned in sterile cap tubes and after identification, sent to the laboratory for microbiological examination.

\section{Articular segment removal and conditioning}

By visualization with a stereomicroscope the dissection of the dried articulation was realized, in average, one articular tecidual segment of 2,0cm (FIGURE 1) one dissected articular segment of the soldra, corresponding to the human knee. This material was then conditioned in glass flask with $10 \%$ formalin solution, identified and sent to the Pathological Anatomy laboratory for histophatological examination. 


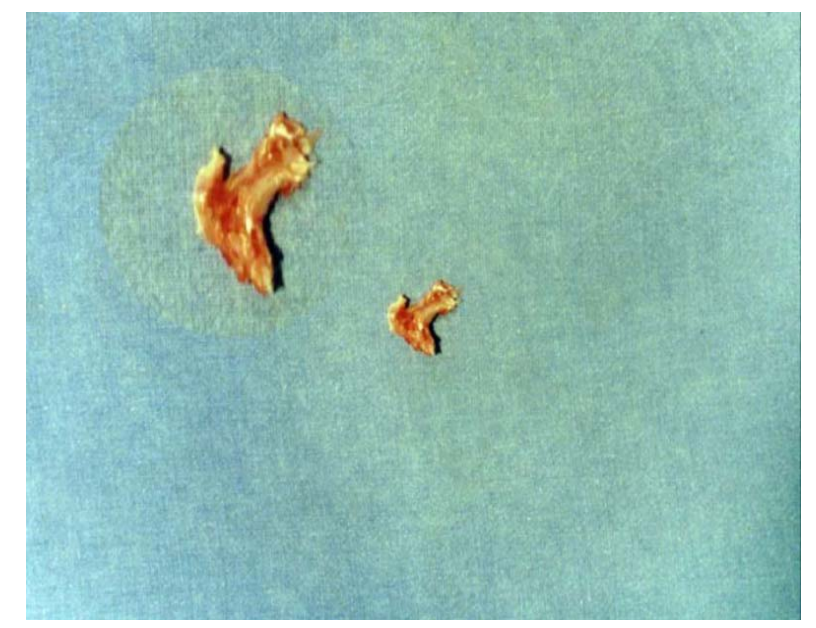

FIGURE 1 - Articular surface cut and surrounding soft tissue after dissection of soldra.

\section{Histopathological examination}

\section{Preparation of histological laminae}

The preparation of the histological laminae was realized in the pathology laboratory, by utilizing the articular tissue cut, conserved with $10 \%$ formalin solution. The tissues were submitted to routine histological procedures. These laminae were previously identified.

For the examination of the histological laminae it was utilized an optical microscope American Optical ${ }^{\circledR}$, biocular with ocular magnification of $10 \mathrm{x}$ and objectives of 10, 25, 40 magnification. For the localization of the cytological field the $10 \mathrm{X}$ objective was employed. The evaluation of the cells was realized with magnification of 400x. The histological field was assayed by taking notes of the histological reactions of the committed tissues of the capsule, from the sinovial and bone tissue in a protocol elaborated for this purpose.

\section{Laboratorial examination}

\section{Hemoculture}

The analysis of the hemocultures collected randomly in pre-established days, were realized as for the control and experimental groups.

\section{Bacteriological examination}

Analysis of the bacteriological examinations of the articulation secretion randomly collected, were realized in pre-established days as for the control and experimental groups.

The demonstrative figures of some control group specimens are shown below, FIGURE 2, and for experimental groups from FIGURES 3 to 8 . 


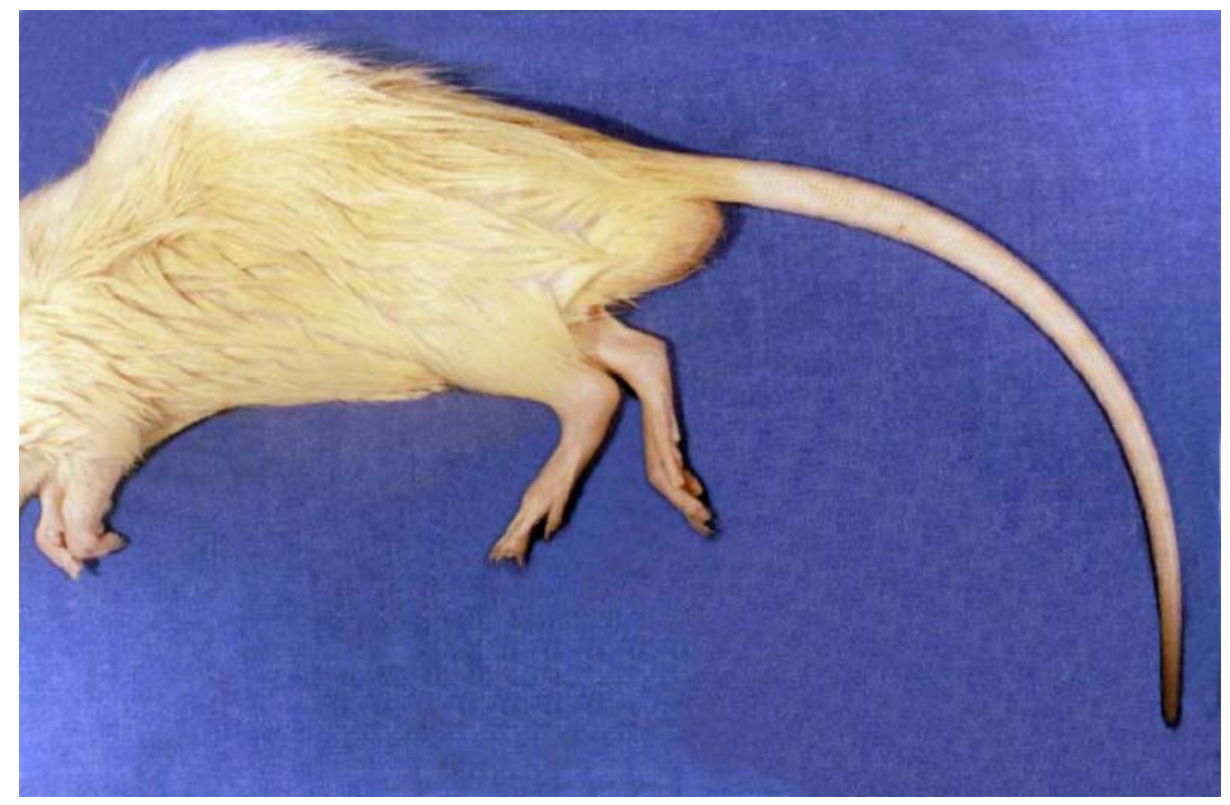

FIGURE 2 - Rat not presenting septic arthritis in the control group.

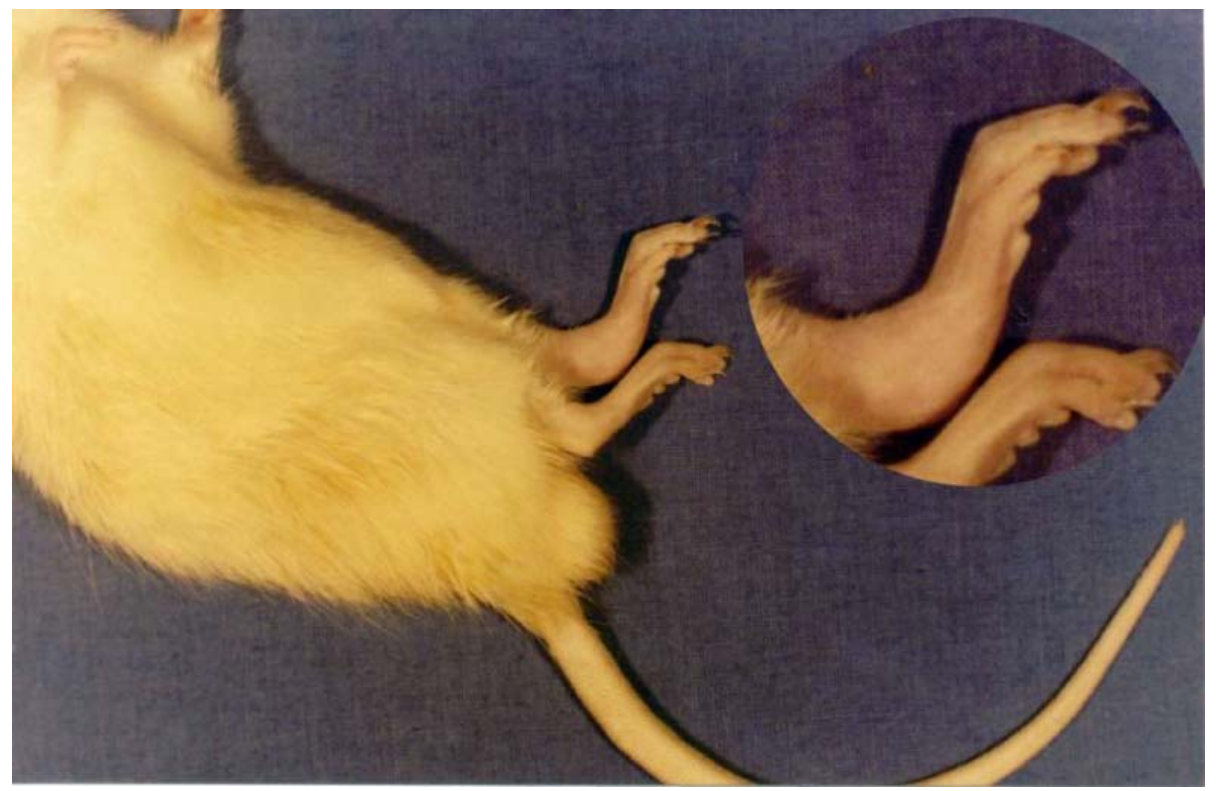

FIGURE 3 - Left caudal foot of the rat presenting septic arthritis. 


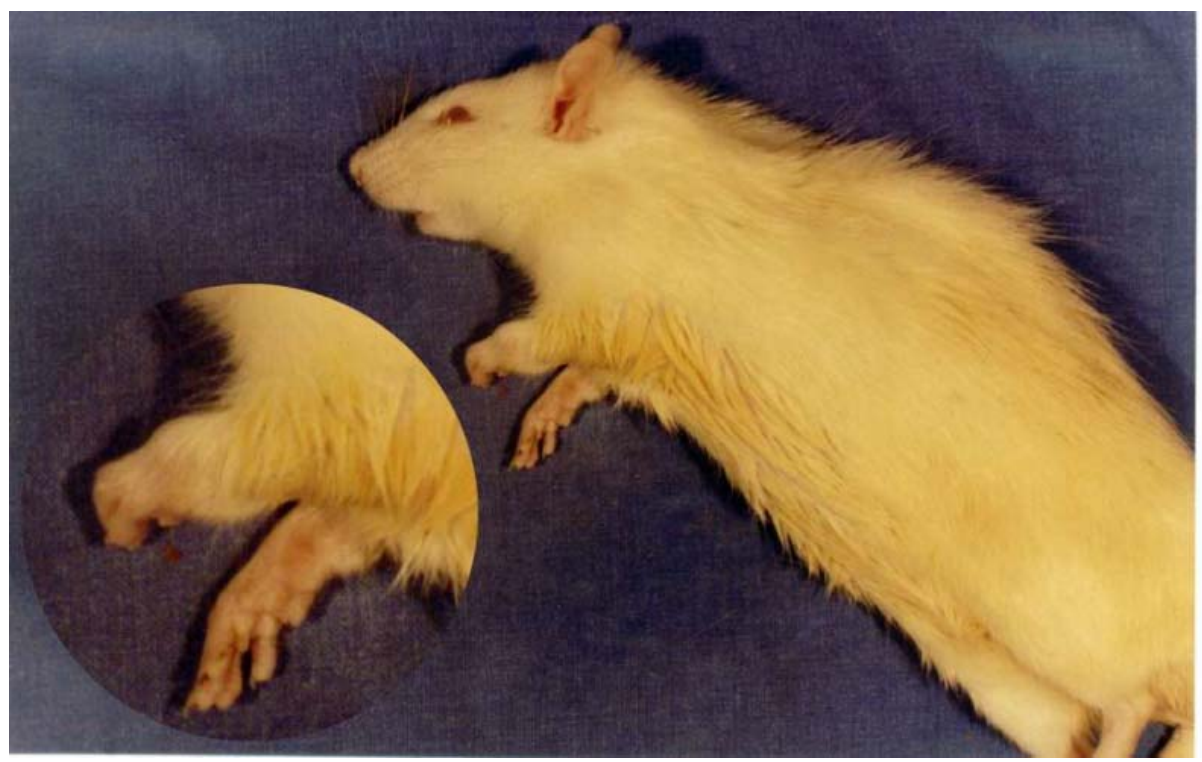

FIGURE 4 - Left cephalod foot of the rat presenting septic arthritis.

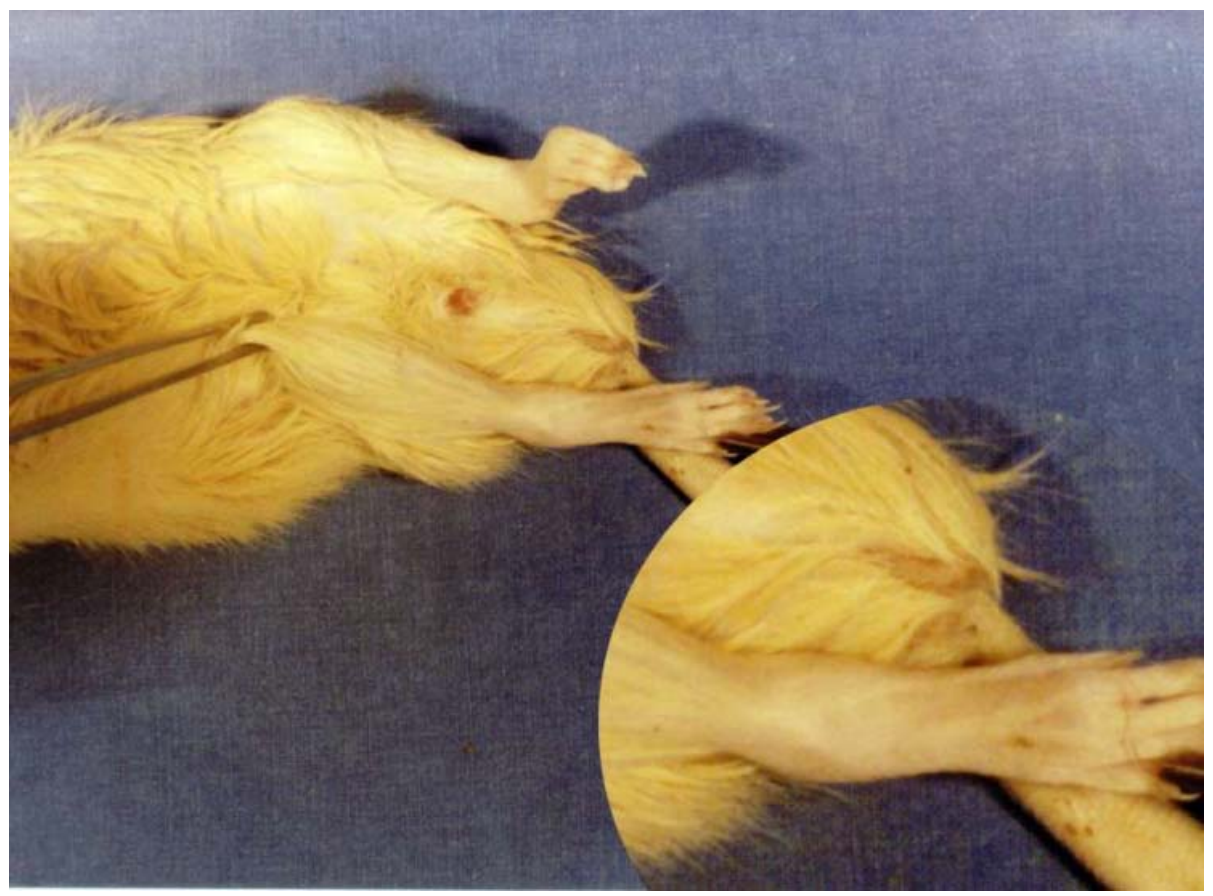

FIGURE 5 - Right caudal foot of the rat presenting septic arthritis. 


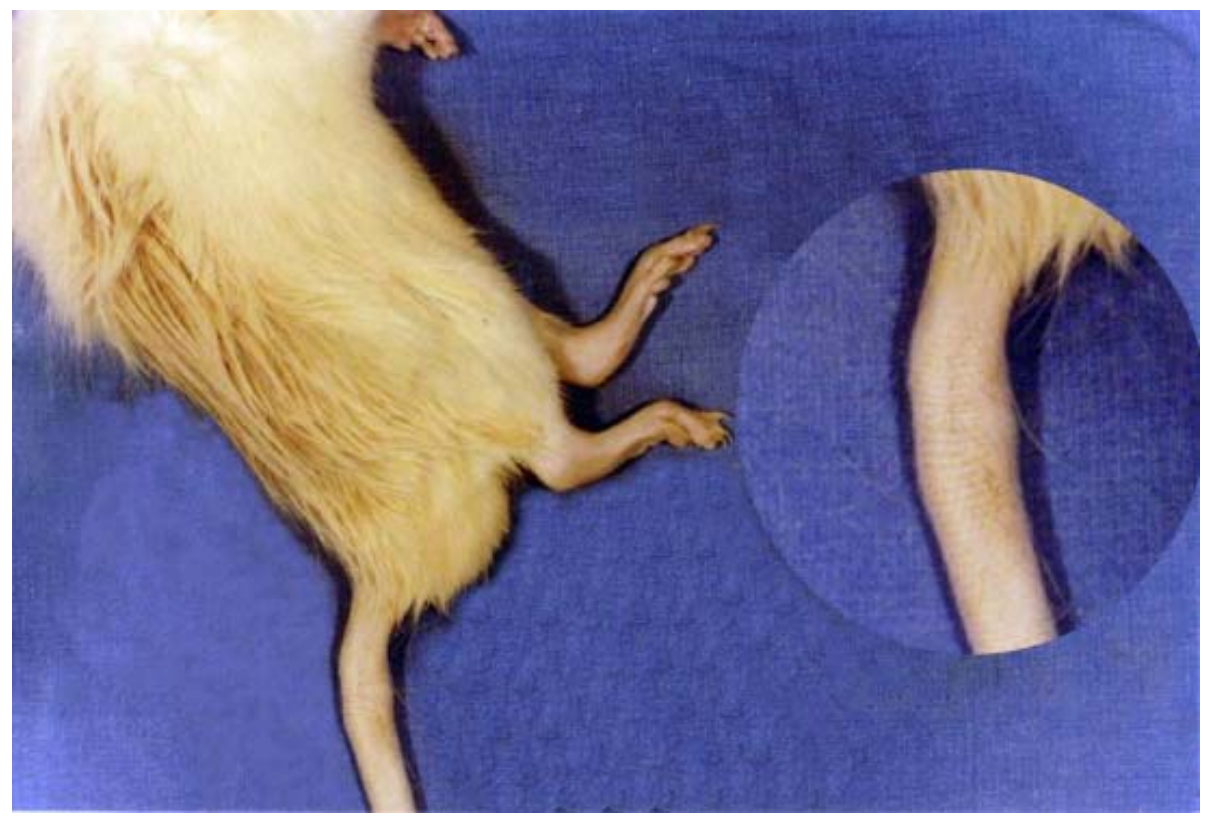

FIGURE 6 - Nodular foot of the rat with septic arthritis.

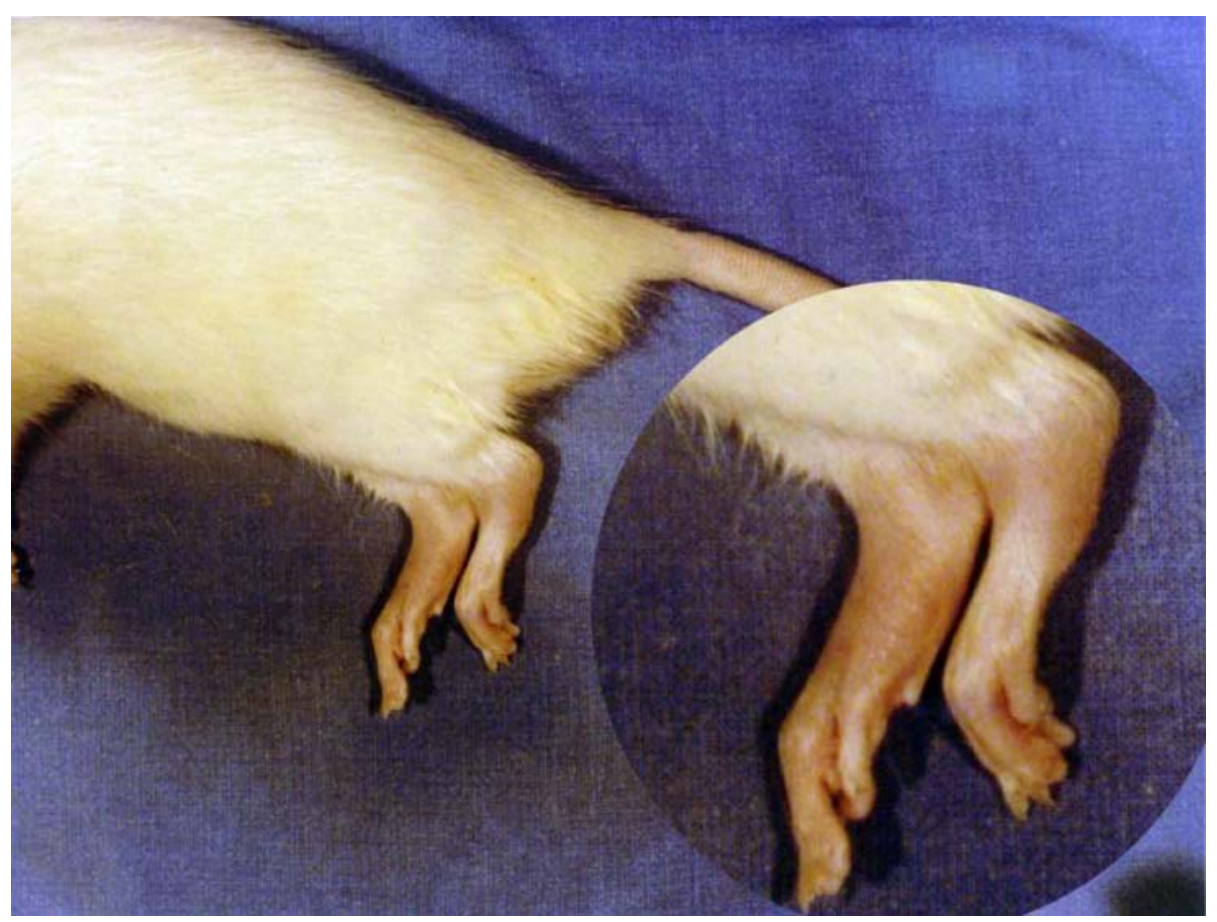

FIGURE 7 - Caudal feet of the rat with septic arthritis. 


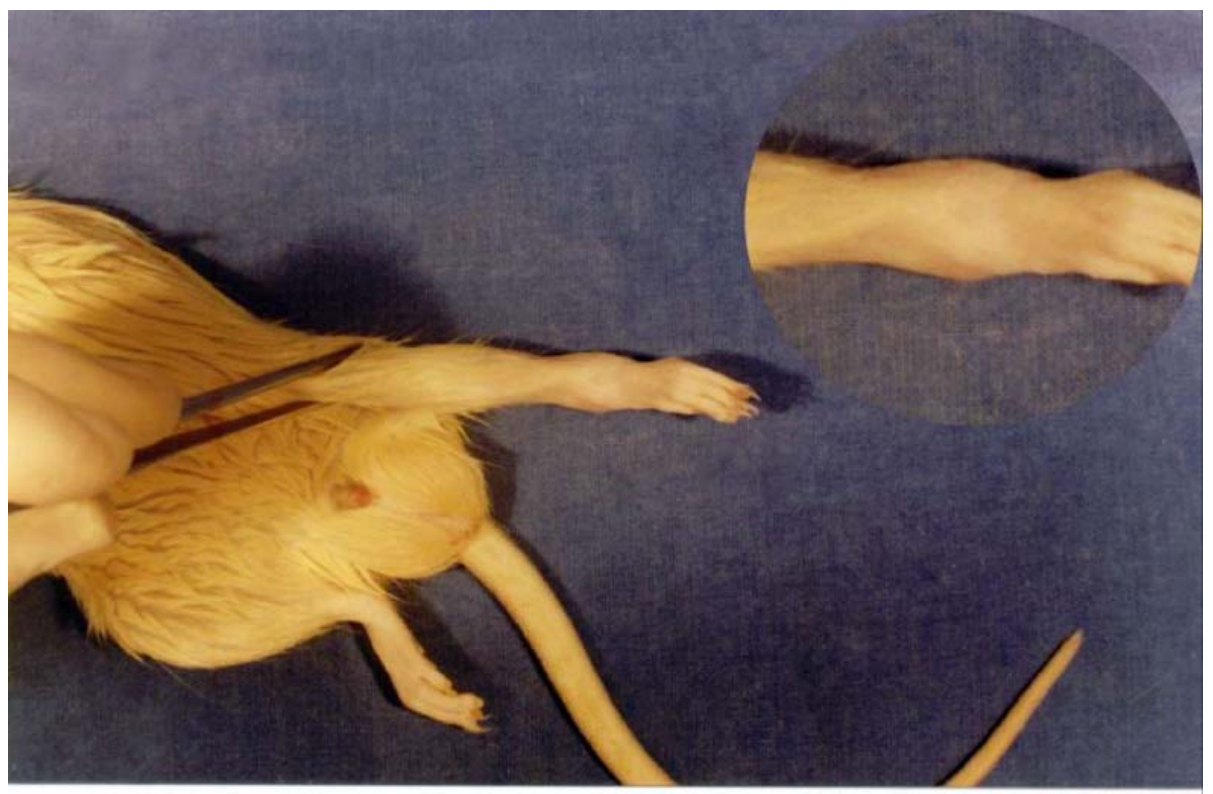

FIGURE 8 - Left caudal feet of the rat with septic arthritis.

\section{Perspectives}

By analyzing the experimental results it can be concluded that the utilization of the monobacterial inoculum of Staphylococcus aureus $10^{9}$, in the rat dorsal penis vein, causes septic arthritis. Therefore the experimental model proposed can be reproducible since the steps described in this procedure are obeyed. In an academic environment the changes are feasible and received when well elaborated.

\section{References}

1. Bremell T, Lange S, Svensson L, Jennische E, Gröndahl K, Carlten H, Tarkowski A - Outbreak of spontaneous staphylococcal arthritis and osteitis in mice. Arthr Rheum Philad. 1990;33(11):1739-44.

2. Bremell T, Lange S, Yacoub A, Rydén C, Tarkowski A - Experimental Staphylococcus aureus arthritis in mice. Infec Immu. 1991:59(8):2615-23.

3. Nassif PAN - Estudo experimental das alterações causadas pela bile humana, cálculos biliares e grampos de titânio na cavidade peritoneal de ratos. Curitiba, 1995. Dissertação (Mestrado em Cirurgia)-Universidade Federal do Paraná.

4. Batista FS - Modelo de artrite séptica por inoculação endovenosa de Staphylococcus aureus em ratos Wistar. [Tese de doutorado]. 2000. Hospital Universitário Evangélico de Curitiba - Faculdade Evangélica de Medicina do Paraná - Instituto de Pesquisas Médicas IPEM/HUEC.

5. Brown GL, Foshee H, Pietsch J, Polk HC - Muramyl dipeptide enhances surgival from experimental peritonitis. Arch Surg. 1986;121:47-49.

6. Dalldorf FG, Anderle SK, Brown RR, Schawab JH - Mast cell activation by A Streptococcoal polysaccharide in the rat and its role in experimental arthritis. Am J Pathol. 1988;132(2):258-64.

7. Hovnanian AP, Saddawi $\mathrm{N}$ - An experimental study of the consequences of intraperitoneal irrigation. Surg Gynecol Obstet. 1972;134:575-8. 
8. Kohashi O, Kohashi Y, Shigematsu N, Ozawa A, Kotani S - Acute and chronic polyarthritis induced by an aqueous form of 6-O-Acyl and N-Acyl derivatives of N-Acetymuramyl-L-alanyl-D-isoglutamine in euthymic rats and athymic nude rats. Lab Invest. 1986;55(.3): 337-46.

9. Mahowald ML - Animal models of onfectious arthritis. Clin Rheum Dis. 1986;12:403-21.

10. d'Arce RD, Flechtmann CHW - Introdução à anatomia e fisiologia animal. 2. ed.São Paulo : Nobel, 1989. $186 \mathrm{p}$.

11. Saad F - Infecção peritoneal. Modelo Experimental em ratos. Acta Cir Bras. 1986;1:10-8.

12. Tomoda K, Kitaoka M, Iyama K, Usuku G - Endosteal new bone formation in the log bones of adjuvant treated in rats. Pathol Res Pract. 1986;181: 331-8.

13. Wiedermann U, Trakowski A, Bremell T, Hanson LA, Kahu H, Dahlgren UI - Vitamin A deficiency predisposes to Staphylococcus aureus infection. Infect Immun. 1996;64(1): 209-214.

14. Zhao Y-X, Abdelnour A, Holmdahl R, Trakowski A - Mice with the Xid B Cell defect are less susceptible to developing Staphylcoccus aureus induced arthritis. J Immunol. 1995;155(4):2067-76.

15. Box WG, Hunter JS - Statistics for expereimenters. New York: Wiley, 1978.

16. Nakamura Y, Masuhara T, Ito-Kuma S, Aoki S - Induction of experimental cândida arthitis in rats. J Med Veterin Mycol. 1991; 29:179-92.

Batista FS, Malafaia O, Ribas Filho JM, Czeczko NG,Repka JCD. Modelo de artrite séptica por inoculação de Staphylococcus aureus em ratos Wistar. Acta Cir Brás [serial online] 2004 Vol 19 Edição Especial. Disponível em URL: http://www.scielo.br/acb.

RESUMO - Descrição de um modelo experimental de artrite séptica por inoculação monobacteriana de Staphylococcus aureus na veia dorsal do pênis de ratos Wistar.

DESCRITORES - Modelo animal. Artrite Infecciosa. Ratos.

Conflito de interesse: nenhum

Fonte de financiamento: nenhum

Correspondence :

Flamarion dos Santos Batista

Padre Anchieta, 1007/ 31

Curitiba - PR CEP 80.430-060

Phone/fax (41) 3363446

flama51@terra.com.br 